\title{
Molecular Analysis of Some Virulence Genes of Salmonellae Isolated from Chicken at Sharkia Governorate
}

Hamza M. Eid*; Azza S. El-Demerdash** and Nosayba M. Hassonna***

*Bacteriology, Immunology and Mycology Department, Faculty of Veterinary Medicine, Suez Canal University (Hamza.eid@vet.suez.edu.eg).

** Microbiology Department Faculty of Veterinary Medicine, Zgazig University (dr.azzasalah@yahoo.com)

***Microbiology Department, Animal Health Research Institute, Egypt.(nosaybahassonna@gmail.com)

\begin{abstract}
Poultry is one of the most reservoirs of Salmonella that can be transmitted to humans through the food chain causing high risk bacterial food poisoning. In the present study, bacteriological examination of 200 samples from broiler internal organs (liver,2ceci, un absorbed yolk sac) from1 day old chicks suffering from omphalitis and respiratory disorders after hatching, revealed 26 Salmonella isolates $13 \%$. Serotyping of 26 Salmonella isolates by slide agglutination test using specific monovalent and polyvalent $\mathrm{O}$ and $\mathrm{H}$ Salmonella sera revealed eleven different Salmonella serotypes, with $S$. Enteritidis as the most prevalent serotype $(38.5 \%)$ followed by $S$. Tamale (23.07\%). , S. Typhymurium (19.2\%), S. Kentucky (15.4\%)and ,S.Heldberg (3.8\%).most Salmonella isolates were sensitive to Ciprofloxacin ,sulfa methoxasole - trimethoprime, Chlorumphenicol and gentamycin .while they were resistant to Erythromycin ,Rifamycin , Amoxycillin /clavulinic acid ,colistin sulfate and cefotaxime . PCR detection of 6verulant genes of 5 strains of Salmonella isolates which proved to play an important role in the virulence of Salmonella in chicken. In this study detection of (invA gene, hilA gene, stn gene, spvc gene, $\mathrm{fmH}$ gene and pefA gene) is with percentages of $(100 \%$, $80 \%, 100 \%, 0 \%, 100 \%$ and $40 \%)$ respectively. From examined 5MDR Salmonella isolates, Integron class1were detected in all of them (100\%) but no strain was found to harbor Integron class2.
\end{abstract}

Key words: Salmonella, virulence,genes, integrin,chicken . 
Introduction

Salmonella isolates are considered as the most circulating and frequent bacterial agents causing disease in poultry and other avian specieS.It is associated with high mortality,morbidity and impaired production Sedeik et al. (2019). Salmonellosis has been associated with infection of broiler flocks that has the ability of vertical transmission to progeny Irshad et al. (2013).

The high prevalence of multidrug resistant Salmonella to be commonly used antimicrobial in veterinary and public health sectors has emerged as a global problem that resulting in treatment failure (Piddock 2002, Molla et al.,2003 and Yan et al., 2003 Khemtong and Chaunchuen 2008).

The present work is planned out as an attempt to throw some spotlights on:

1. Isolation of Salmonella serovars from different poultry farms.

2. Biochemical and serological identification of Salmonella isolates.

3. Antimicrobial sensitivity test on Salmonella isolates.

4. Genotypic characterization of obtained Salmonella isolates to detect the most predominant virulence genes.

5. Detection of class1 and cass2 integrin in multi-drug resistant isolates by polymerase chain

reaction

\section{Mate rials and Methods}

1. sampling

200 samples from broiler internal organs (liver,2ceci, un absorbed yolk sac) from1 day old chicks suffering from omphalitis and respiratory disorders after hatching. samples were collected aseptically to prevent cross contamination by wearing disposable gloves and using sterile sampling materials (swabs, bags and syringes). The samples were collected and transported in ice boxes with ice packs as early as possible to the laboratory for bacteriological examination and keeping on refrigerator.

2 Isolation of Salmonella, biochemical identification and serotyping

We follow ISO 6579 (2002) procedure. Suspected Salmonella colonies were confirmed serologically by Kauffman - White scheme (Kauffman, 1974) for the determination of $(\mathrm{O})$ and $(\mathrm{H})$ antigens using Salmonella antiserum (DENKA SEIKEN Co., Japan). and biochemically by (TSI) test, Urea hydrolysis test, Lysine decarboxylation test, Indole production test and Simmon Citrate utilization test. The isolates were then serotyped by the Animal health research institute in Dokki -Giza. Only 
confirmed Salmonella were tested for their susceptibility to different antibiotic and the presence of the virulant gnes class 1 and class 2 integron.

3 Resistance to the antimicrobial agents

We detect susceptibility of isolates to antimicrobial agents following the Clinical and Laboratory Standards Institute (Clinical and Laboratory Standards Institute, CLSI, 2007) for the disk diffusion technique. The antimicrobials and concentrations tested were Amoxicillin/clavulanic acid, Norfloxacin, Gentamicin, Cefotaxim, Sulfamethoxazole/ trimethoprim, Ciprofloxacin, Nalidixic acid, Doxycyclinem, Erythromycin, Chloramphenicol, Colistin sulphate,Rifamycin The inhibition zones were scored as sensitive, inter- mediate susceptibility or resistant according to the CLSI .

4 Polymerase chain reaction for amplification of the most important virulent genes of Salmone lla isolates (invA gene, hilA gene, stn gene, spvc gene, $\mathrm{fmH}$ gene and pefA gene)

a.Extraction of DNA according to QIAamp DNA mini kit instructions.

b. Preparation of PCR Master Mix according to Emerald Amp GT PCR mastermix (Takara) Code No. RR310A kit.

\section{Results \&Discussion}

Results revealed 26 Salmonella isolates from200 samples with percentage (13\%). Serotyping of 26 Salmonella isolates by slide agglutination test using using specific monovalent and polyvalent $\mathrm{O}$ and $\mathrm{H}$ Salmonella sera detected eleven different Salmonella serotypes, with S. Enteritidis as the most prevalent serotype $(38.5 \%)$ followed by S.Tamale $(23.07 \%)$, S. Typhymurium (19.2\%), S. Kentucky (15.4\%)and ,S.Heldberg (3.8\%).most Salmonella isolates were sensitive to Ciprofloxacin ,sulfa methoxasole - trimethoprime, Chlorumphenicol and gentamycin .while they were resistant to Erythromycin ,Rifamycin , Amoxycillin /clavulinic acid ,colistin sulfate and cefotaxime.

Examination of samples collected from diseased and died saso chicks from different hacharies in Sharkia using SMT,26 Salmonella isolates was isolated in an over prevalence of $13 \%(26 / 200$. The results of serological identification in present study detected 5 different serovars from 26 Salmonella isolates, $\quad S$.Entertides predominated with higher percentage $(38.5 \%)$ while the remained isolates were serotyped as.

S.Tamale, $\quad S$.Typhymurium, S.Kentucky, $\quad$ S.Heldberg,with percentages (23.07\%), 
$(19.2 \%)$

,(15.4\%),(3.8\%), repectively.

Genotypic characte rization of some Salmonella serotypes:

S.Enteritides

(105),S.Tamale(13),S.Typhimur ium(17),S.Kentucky and

S.Heldberg (97) were subjected to PCR genotyping for detection of some virulent genes(inv A, fimH,hila,pef,andspvC $\mathrm{C}$ )and Integron(Int1 and Int2) .

It was evident that the oligonucleotide primer pairs targeting the genes under study successfully amplified the DNA extracted from tested Salmonella isolates for each primer.

As expected, PCR confirmation of bacteriology positive strains was documented by appearance of amplified DNA fragment of 284bp for the invA gene, a target for Salmonella genus in all examined serotypes $(100 \%)$

Detection of class 1 integron and class 2 integron among multidrug resistant is olates:

From examined 5MDR

Salmonella isolates, Integron class1were detected in all of them $(100 \%)$ but no strain was found to harbor Integron class $2(0 \%)$ as shown in figures $7 \& 8$.

Association between phynotypic antimicrobial results and genotypic detection of some virulence genes of different Salmonella species could be effective in providing a more accurate profile for understanding the dangerous spread of virulence genotypes and antibiotics resistance in Salmonella serovars.

From the above mentioned results, it is important to note that amplification of invA gene as Salmonella species specific and virullance factor in this study produced a PCR product of approximately 284bp in all Salmonella species tested100\%). All 5 Salmonella serotypes which Identified phenotypically were found to possess invAgene indicating that PCR result from invAgene detection in agreement with these of conventional methods.

Several authors proposed a rapid, sensitive and specific PCR method using primers for invA gene for the detection of Salmonella serotypes in may clinical samples within a maximum of $12 \mathrm{hr}$, thus confirming its affiliation to Salmonella species (Lampel et al.,2000; ferretti et al.,2001; schneder et al 2002 and Ammar et al.,2014).

In addition, oliveria et al. (2002) and Malorny et al. (2003) and Lin et al. (2007) reported that invAgene abled to identify all eamined Salmonella serovar by PCR technique.

In the last decade, there has been a wide interest in the use of PCR technique. PCR have been 
applied to detect different species of several microorganisms, to differentiate closely related species Settani and Corsetti, (2007). The primary advantages of PCR tests are increased sensitivity and less time required to process samples in the laboratory when compared to standard culture method Lampel et al. (2000).

In the present work, PCR approaches have been applied to dtect different virulent genes that are (invA,hilA, pefA,stn,spvc and fimH ) and also detect integron class 1 and integron class 2 that is responsible for antibiotic resistance .

Finally, amplification of invA and hliA genes now has been recognized as an international standard for detection of genus Salmonella Maloeny et al. (2003).

It is alarming that Salmonella induced diarrhea is a complex phenomenon involving several pathogenic mechanisms including production of enterotoxin which is mediated by stn gene. Therefore, a uniplex PCR assay was carried out for detection of this gene in the representative Salmonella isolates. The results revealed the presence of stn gene in all tested Salmonella isolates with a PCR product at $619 \mathrm{bp}$. This finding is in a greement with earlier reports of Parger et al. (1995) and Morogkar et al. (2003) who detected stn gene among different Discussion 78 Serovars of Salmonella,indicating that stn gene is widely distributed among Salmonella irrespective of their Serovars and source of isolation. Moreover, fimbriae play an important role in the pathogenicity of bacteria which is a key factor for bacteria invasion and survival inside the host cells Finaly and falkow (1989). PefA gene is encoded by pef operon located in a plasmid Friedrich et al. (1993).

Indeed, among the isolates analysed in this study pefA gene was present in $40 \%$ of these isolates. This result is go hand in hand with Mona 2014 that dectect pefA with percentage $41.1 \%$. On the contrary this result is markedly lower than that presented byWood Ward et al. (1996) who found that $97.9 \%$ of $S$.Entertidis isolates was positive for the presence of this gene and Morugkar et al. (2003) who found pefa in $89 \%$ of different Salmonella serovars in India.

Furthermore, Salmonella is plasmid virulence (spvc) is also related to survival and growth of the bacterium in host cells Swamy et al. (1996).

In this study, no isolate of Salmonella was positive for the presence of spvc gene that is differ from than that observed by Amini et al. (2010) who detecyed spv in $30 \%$ of 
S.enteritidis strains isolated from poultry and Ihab et al. (2013) who found that the incidence of spvc genes was $31.5 \%$ in $S$.Enteritidis and $30 \%$ in $S$ .Typhymurium isolates from poultry.

Salmonella enterica serovar Enteritidis is presently the major causative agent of food born gastro enteritis in human worldwide and an important source of bacterial infection on poultry farms resulting in public health problems and economic loss .Infection by $S$. Enteritidis is initiated by the attachment and colonization of gut mucosa ,which seem to be essential stage in the pathogenesis of salmonellos is .Increasing Discussion 78 evidence suggests that bacterial fimbriae play an important role in these processes Dagmara (2006).

$S$.Enteritidis genome contains many putativefimbrial operons :afg,bcf,fim and pef Edward et al. (2002).

Studies on $S$.Typhymurium revealed that FimH adhesion is responsible for bacteria binding to intestinal epithelial cells Thankavel et al. (1999).

The fim $\mathrm{H}$ gene produced an amplified PCR product at164bpin all Salmonella tested. S. enterica serovar Typhymurium express type 1fimbriae that enable the bacteria to bind to eukaryotic cell and have been implicated in mediation.

We have previously shown that fim $\mathrm{H}$ mutants of Salmonella are unable to adhere to eukaryotic cell, demonstration that FimH is critical for the ability of type 1 fimbriae to specifically bind to host cells Brett et al. (2011).

Association between phynotypic antimicrobial results and genotypic detection of some virulence genes of different Salmonella species could be effective in providing a more accurate profile for understanding the danderous spread of virulence genotypes and antibiotics resistance in Salmonella serovars. Overall, multidrug resistant Salmonella serotypes were also cabable for exhibiting several virulence determinants which are very important to induce Salmonella pathogenicity. This result corresponds closely to a previous report published by Amminin et al. (2011) who found the virulence gene invA, hila located Discussion 77 on SPI-1 and other virulence genes not present on it such as stn and spvc were detectable in all multidrug resistant Salmonella isolates.

It is important to note that Salmonella can easily acquire multiple drug resistance to most antimicrobial and transform them to human through food chain. 
Recently, the generation and the transformation mechanism of the drug resistance gene have become a hot research topic in order to control the spread of multi drug resistance bacteria.

Integron, a noval DNA element, mediating the integration of antibiotic resistance gene through site specific recombination has great impact on human health. The back bone structure of an integron is probably the most prevalent type of integrin harboured by such isoltes Sunde.2005 and Ren et al. (2013).

In the present study, class 1 integron and class 2 integron, was screened among 5 multidrug resistance Salmonella strains using specific primer for integrase (IntI1) and (IntI2) gene The result revealed the presence of class1 integrin in all tested serotypes and absence of class 2 integrin in all tested serotypes. Other reports have also revealed the prevalence of class 1 integron in gram negative isolates from food samples as 41.3\% in united states Khaista et al. (2008), $45 \%$ in china $\mathrm{Li}$ et al.(b2011), $49 \%$ in Australia White et al. (2001) 99\% In Bortugal Antunes et al. (2004) Indicating that class 1 integron are wide spread among gm - ve isolates.

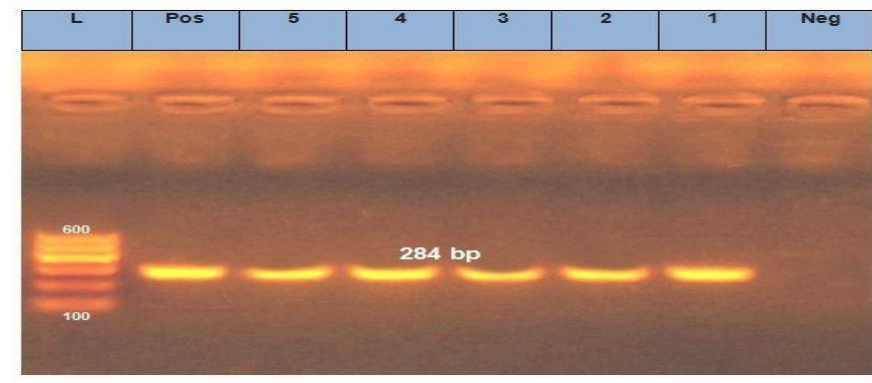

Fig (1): Agarose gel electrophoresis showing the result of PCR for detection of invAgene from 5Salmonella strains

Lanes 1,2,3,4,5: Salmonella species

Lane Pos: positive invA control.

Lanes 1,2,3,4,5: positive amplification of 284bp for invA gene of different Salmonella species.

Lane L: the DNA molecular weight marker (Gelpilot 100bp ladder).

Lane Neg: negative invA control. (control negative). 


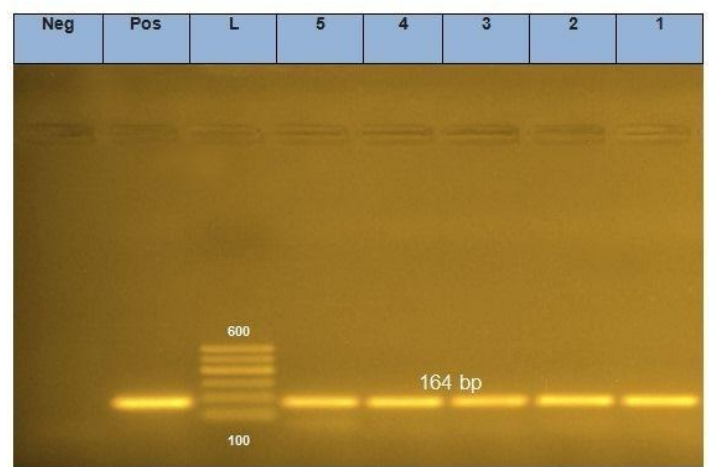

Fig. (2): Agarose gel electrophoresis showing the result of PCR for detection of fim $\mathrm{H}$ gene from5 Salmonella strains

Lanes 1,2,3,4,5: Salmonella species

Lane Pos: positive fimH control.

Lanes 1,2 ,3,4 and5: positive amplification of 164bp for fimH gene of different Salmonella species.

Lane L: the DNA molecular weight marker (Gelpilot 100bp ladder). Lane Neg: negative fimH control. (control negative).

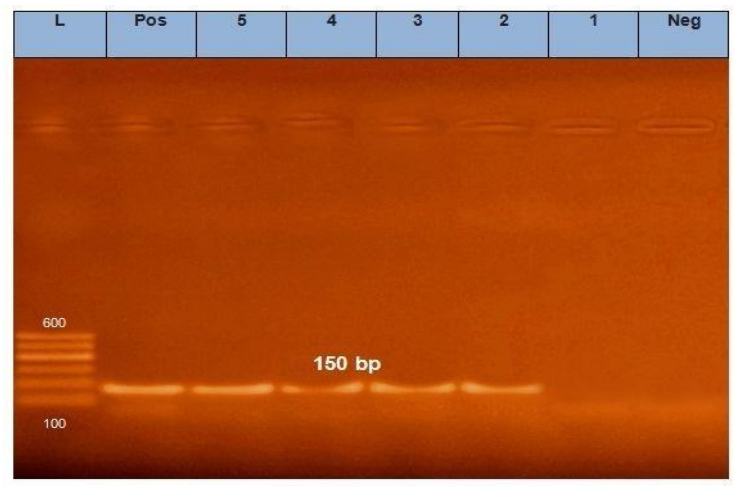

Fig. (3): Agarose gel electrophoresis showing the result of PCR for detection of hil A gene from5 Salmonella strains

Lanes 1,2,3,4,5: Salmonella species

Lane Pos: positive hil A control.

Lanes $2,3,4$ and5: positive amplification of 150bp for hil A gene of different Salmonella species.

Lane 1: negative amplification of 150bp for hil A gene of different Salmonella species.

Lane L: the DNA molecular weight marker (Gelpilot 100bp ladder). Lane Neg: negative hil A control. (control negative). 


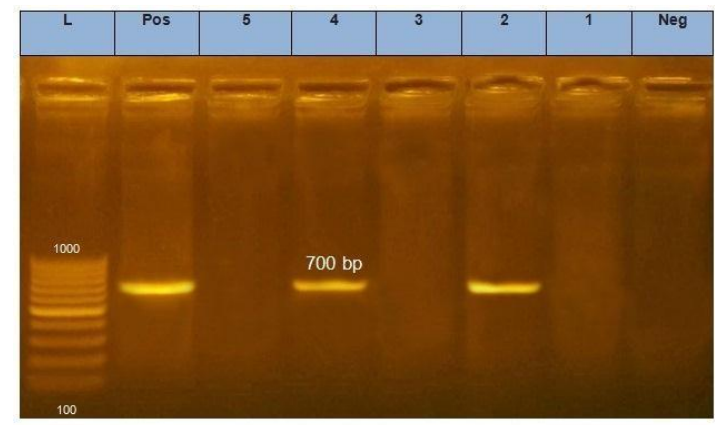

Fig. (4): Agarose gel electrophoresis showing the result of PCR for detection of pef gene from5 Salmonella strains

Lanes 1,2,3,4,5: Salmonella species

Lane Pos: positive Pef control.

Lanes 2 and4: positive amplification of 700bp for Pef gene of different Salmonella species.

Lanes 1,3 and5: negative amplification of 700bp for Pef gene of different Salmonella species.

Lane L: the DNA molecular weight marker (Gelpilot 100bp ladder)

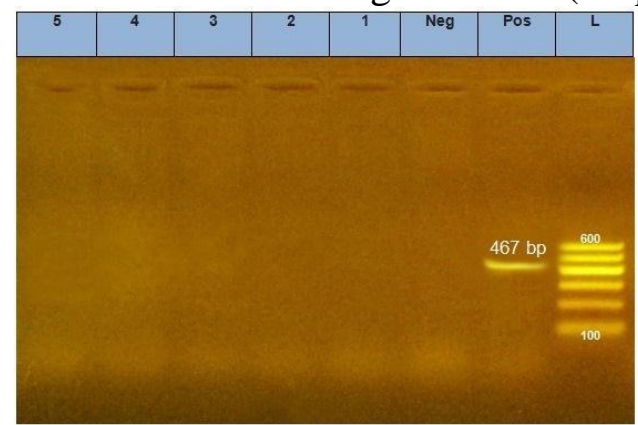

Fig. (5): Agarose gel electrophoresis showing the result of PCR for detection of $s p v \mathrm{C}$ gene from5 Salmonella strains

\section{Lanes 1,2,3,4,4,5 Salmonella species}

Lane Pos: positive $s p v C$ control (refrence strain).

Lanes 1,2,3,4, 5: negative amplification of $467 \mathrm{bp}$ for $s p v C$ gene of different Salmonella species.

Lane L: the DNA molecular weight marker (Gelpilot 100bp ladder).

Lane Neg: negative $s p v C$ control. (control negative) 


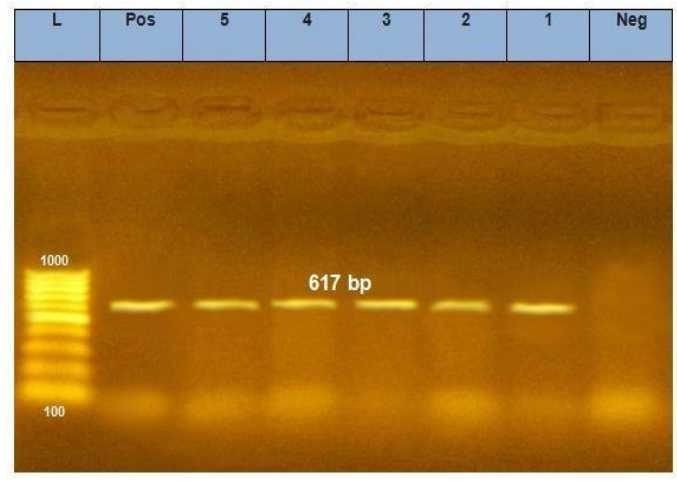

Fig. (6): Agarose gel electrophoresis showing the result of PCR for detection of stn gene from5 Salmonella strains

\section{Lanes 1,2,3,4,4,5 Salmonellaspecies}

Lane Pos: positive stn control (refrence strain

Lanes 1,2,3,4,5: positive amplification of 617bp for qnrS gene of different Salmonella species.

Lane L: the DNA molecular weight marker (Gelpilot 100bp ladder).

Lane Neg: negative stn control. (control negative).

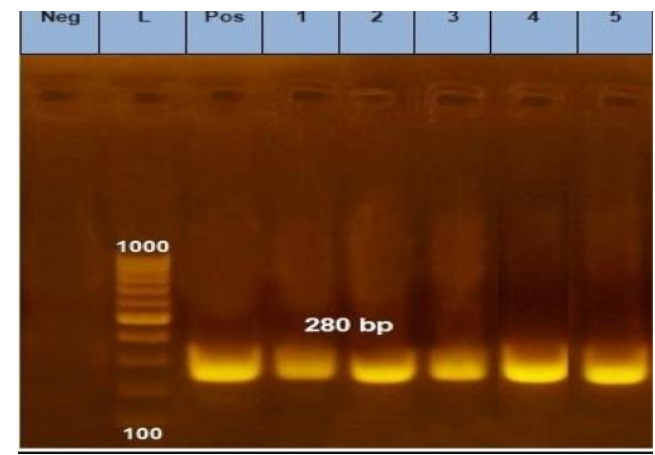

Fig. (7): Agarose gel electrophoresis showing the result of PCR for detection of Intl from5 Salmonella strains

Lanes 1,2,3,4,4,5 Salmonella species

Lane Pos: positive Int1 (refrence strain

Lanes 1,2,3,4,5: positive amplification of 280bp for Int1 of different Salmonella species.

Lane L: the DNA molecular weight marker (Gelpilot 100bp ladder). Lane Neg: negative Int1 control. (control negative). 


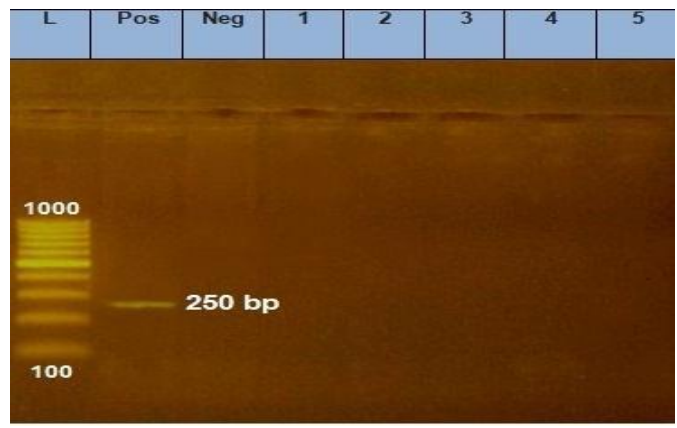

Fig. (8): Agarose gel electrophoresis showing the result of PCR for detection of Int2from5 Salmonella strains

Lane 1 1,2,3,4,4,5 Salmonella species

Lane Pos: positive Int 2 control (refrence strain).

Lanes 1,2,3,4, 5: negative amplification of 250bp Int2 of different Salmonella species.

Lane L: the DNA molecular weight marker (Gelpilot 100bp ladder).

Lane Neg: negative Int2 control. (control negative).

Based on the phenotypic and genotypic characterization,the isolates were categorized in five different well defined profiles as shown in table()

Table (1): Relationship between drug resistance and presence of virulent genes, Int 1 and Int 2 among Salmonella isolates:

\begin{tabular}{|c|c|c|c|c|c|}
\hline $\begin{array}{l}\text { Code } \\
\text { No. }\end{array}$ & $\begin{array}{c}\text { Sample } \\
\text { origin }\end{array}$ & $\begin{array}{c}\text { Antimicrobial sensitivity } \\
\text { (R\&I) }\end{array}$ & $\begin{array}{l}\text { Virulent } \\
\text { genes }\end{array}$ & Int 1 & Int 2 \\
\hline $105 S . E$ & Liver & $\begin{array}{l}\text { AMC-S-NA-CTX- SXT--E-C-CT- } \\
\text { RF. }\end{array}$ & InvA-stn-fimH. & + & - \\
\hline 13 S.Ta & Liver & CTX-E-CT-RF & $\begin{array}{l}\text { invA-hilA-stn } \\
\text { pefA-fimH. }\end{array}$ & + & - \\
\hline 17 S.Ty & $\begin{array}{l}\text { Yalk } \\
\text { Sac }\end{array}$ & S-CN-NA- CTX- DO-E-C-CT-RF. & $\begin{array}{l}\text { invA-hilA-stn } \\
\quad \text { fimH. }\end{array}$ & + & - \\
\hline $33 S . \mathbf{K}$ & Liver & $\begin{array}{l}\text { AMC-NA-CTX- SXT-DO-E-C-CT- } \\
\text { RF. }\end{array}$ & $\begin{array}{l}\text { invA-hilA-stn } \\
\text { pefA-fimH. }\end{array}$ & + & - \\
\hline $97 S . H$ & 2ceci & AMC-CN-NA-CTX- E-CT-RF. & $\begin{array}{l}\text { invA-hilA-stn } \\
\text { fimH. }\end{array}$ & + & - \\
\hline
\end{tabular}

\section{References}

Ammar AM1, Mohamed AA, Abd El-Hamid MI, ElAzzouny M. M. (2016): Virulence genotypes of clinical SalmonellaSerovars from broilers in Egypt. J Infect Dev
Ctries. 28;10(4):337-46. doi: 10.3855/jidc. 7437 .

Ammar AM, Abde en EE, AboShama UH, Fekry E, Kotb Elmahallawy E. (2019): Molecular characterization of virulence and antibiotic 
resistance genes among

Salmonella serovars isolated from broilers in Egypt. Lett Appl Microbiol. 2019 Feb;68(2):188195. doi: 10.1111/lam.13106. Epub 2019 Jan 6.

Amini K., Zahraei T., Nikbakht G., Ranjbar R., Javid Amini, J. and Ashrafganjooe, S. (2010): Molecular detection of invA and $s p v$ virulence genes in Salmonella Enteritidis isolated from human and animals in Iran. Afr. J. Microbiol. Res., 4 (21): $2202-2210$.

Ammini P, Jasna V, Grees hma M, and Preethi C (2011): Comparative virulence genotyping and antimicrobial susceptibility profiling of environmental and clinical Salmonella enterica from Cochin, India. Curr. Microbiol.,62(1): 21-26.

Antunes P, Machado J, Sousa $J C$ and Piexe L (2004): Dissemination amongst humans and food products of animal origin of a Salmonella Typhimurium clone expressing an integron-borne OXA-30 Blactamase. J. Antimicrob. Chemother. 54: 429-434.

Brett E. Dwyer, Karly L. Newton, Dagmara Kisiela, Evgeni V. Sokurenko, and Steven Clegg (2011): Single nucleotide polypmorphisms of fimH associated with adherence and biofilm formation by serovars of Salmonella enterica.
Microbiology. 2011 Nov; 157(Pt

11): 3162-3171.

\section{Dagmara Kisiela, Anna}

Laskowska, Anna Sapeta,

Maciej Kuczkowski ,Alina

Wie liczko and Maciej

Ugorski(2006): Functional

characterization of the FimH

adhesion from Salmonella

enterica serovar Enteritidis ,

Microbiology , 152, 1337-1346.

Edwards, R. A., Olsen, G. J. \&

Maloy, $S$ R. (2002):

C.omparative genomics of closely related Salmonellae. Trends Microbiol 10, 94-99.

Ferretti R, Mannazzu L , Cocolin L, Comi G. and Clementi F (2001): Twelvehours PCR-based method for detection of Salmonella spp, In food. Appl. Environ. Microbiol., 74: 977-978.

Finlay B. and Falkow S (1989): Common Themes in Microbial Pathogenicity. Microbiol. Rev., 53: 210-230.

Friedrich M J, Kinsey $\mathbf{N}$, Vila J, Kadner R J (1993): Nucleotide sequence of a $13.9 \mathrm{~kb}$ segment of the $90 \mathrm{~kb}$ virulence plasmid of Salmonella typhimurium: the presence of fimbrial biosynthetic genes. Mol. Microbiol, 8 (7): 543-558.

Ihab M M , Yosra $\mathbf{S}$ A, Abdullah A A, Ashgan M H Azza $S \quad G$ and Refai $M$ K.(2013): Molecular characterization of Salmonella virulence genes isolated from different sources relevant to 
human health.Journal of Food, Agriculture and Environment., 11 (2): 197-201.

Irshad B.,Asad AA., Iftikhar M.,(2013): the prevalence of Salmonellosis in poultry farm and around district Kosur Pakistan. Sci int .2013;25(3)603604.

ISO 6579 (2002): Microbiology of food and animal feeding stuffs. Horizontal methods for the detection of Salmonella species. ( $4^{\text {th }}$ ed.) international Organization for standardization.

Kauffiman

F.

Serological diagnosis of

Salmonella spp. Kaufmann White Scheme, Copenhagen, Denmark.

Khaitsa ML, Oloya J, Doe tkott $D$ and Kegode R. (2008): Antimicrobial resistance and association with class 1 integrons in Escherichia coli isolated from turkey meat products. J. Food Prot.; 71(8):1679-1684.

Khemtong

S.,Chaunchven

R.(2008):class 1 integron and Slmonella genomic island 1 among Salmonella enterica isolated from poultry and swine .Microb. Drug Resist. 14 65-70.

Lampel K A, Orlandi P A and Kornegay L (2000): Improved template preparation for PCRbased assay for detection of food-borne bacterial pathogens. Appl. Environ. Microbiol., 66 (10): 4539-4542.
Lin C L, Chiu C H, Chu C, Huang Y C, Lin T Y and Ou J $T$ (2007): A multiplex chain reaction method for rapid identification of Citrobacter freundii and Salmonella species, including Salmonella Typhi. J. Microbiol. Immunol. Infect., 40 (3): 222-226.

Malorny B, Hoorfar J, Bunge $C$ and Helmuth $R$ (2003): Multicenter validation of the analytical accuracy of Salmonella PCR: towards an international standard. Appl. Environ. Microbiol., 69 (1): 290296.

Malorny B, Paccas soni E, Fach $P$, Bunge $C$, Martin $A$ and Mclmufli R (2004): Diagnostic real- time PCR for detection of Salmonella in food. Appl. Environ. Microbiol., 70 (12): 7046-7052.

Molla B, Mesfin A and Alemayeh U D (2003): Multiple antimicrobial-res istant

Salmonella serotypes isolated from chicken carcasses and giblets in Debre Zeit and Addis Ababa, Ethiopia. Ethiop. J. Health Dev., 17: 131-149.

Murugkar, H.V.; Rahman, H. and \& Dutta, P.K. (2003): Distribution of virulence genes in Salmonella serovars isolated from man \& animals. Indian $\mathbf{J}$ Med Res., 117:66-70.

Oliveira S D, Santos L R, Schuch D M T, Silva A B, Salle C T P and Canal C W (2002): Detection and identification of 
Salmonellas from poultry by PCR. Vet. Microbiol., 87(1): 2535.

Olivera, S.D.; Rodenbusch, C.R.; Ce, M.C.; Rocha, S.L.S. and Canal, C.W. (2003): Evaluation of selective and nonselective enrichment PCR procedures for Salmonella detection. Lett. Appl. Microbiol., 36: 217-221.

Oliveira W F, Cardoso W M, Salles R P R, Romão J M, Teixeira Câmara S R, Siqueira $A$ and Marques $L \quad C \quad L$ (2006): Initial identification and sensitivity to antimicrobial agents of Salmonella spp. isolated from poultry products in the state of Ceara, Brazil. Rev. Bras. Cienc Avic 8 (3): 193 199.

Piddock L.J. (2002):

Flouroquinolone resistance in Salmonella serovars isolated from human and food animals.FEMS.Microbiol.Rev.2 6 3-16.

Prager R, Fruth A and Tschäpe H (1995) Salmonella enterotoxin (stn) gene is prevalent among strains of Salmonella enterica, but not among Salmonella bongori and other Enterobacteriaceae. FEMS Immunol

Med.

Microbiol.,12:47-50.

Prager R, Mirold S, Tietze E, Strutz U, Knuppel B and Rabsch W (2000): Prevalence and polymorphism of genes encoding translocated effector proteins among clinical isolates of Salmonella enterica. Int. J. Med. Microbiol., 290: 605-617.

Ren C, Zhao $Y$ and Shen Y. (2013): Analysis of the effect of integrons on drug-resistant Staphylococcus aureus by multiplex PCR detection. Molecular Med. Reports; 7(3): 719-724.

Sedeik ME, El-Shall NA, Awad AM, Elfeky SM, Abd El-Hack ME, Huss ein EOS, Alowaimer AN, Swelum A.A. (2019): Isolation, conventional and molecular characterization of Salmonella spp. from newly hatched broiler chicks. AMB Express. $\quad 30 ; 9(1): 136$. doi: 10.1186/s 13568-019-0821-6.

Schneder A C, Gronewald, Fandke M, Kurth B, Barkowski $S$ and Berghof Jager K (2002): Real-time detection of the genus Salmonella with the Light Cycler system., Biotecon Diagnostics $\mathrm{GmbH}$, Potsdam, Germany.

Sunde M. (2005): Prevalence and characterization of class 1 and class 2 integrons in Escherichia coli isolated from meat and meat products of Norwegian origin. J. Antimicrobia 1

Chemother.;56(6): 1019-1024.

Swamy S C, H M Barnhart M $D$, Lee and Dreesen D W (1996): Virulence Determinants inv $\mathrm{A}$ and $s p v \mathrm{C}$ in Salmonellae Isolated from Poultry Products, Waste water and Human 
Sources. Appl. And Environ. Microbiol., 62: 3768-3771.

Thankavel, K., Shah, A. H., Cohen, M. S., Ikeda, T., Lorenz, R. G.,Curtis s, R. \& Abraham, S. N.

(1999):Molecular basis for the enterocyte tropism exhibited by Salmonella typhimurium type 1fimbriae. J Biol Chem 274, 55797-55809.

White D G, Zhao S, Sudler R, Ayer S and Friedmon S (2001): The isolation of antibiotic resistant Salmonella from retail ground meats. N. Engl. J. Med., (16): 1147-1154.

Wood M W, Jones M A, Watson P R, Hemges $S$ Wallis T S and Galyor E E (1998):
Identification of pathogenicity island required for Salmonella enteropathogenicity. Mol. Microbiol., 29(3): 883-891.

Woodward M J, Allen-Vercoe E and Redstone J S. (1996):

Distribution gene sequence and expression in vivo of the plasmid encoded fimbrial antigen of Salmonella serotype Enteritidis. Epidemiol. Infect., 117 (1): 1728.

Yan S S, Pendrak M L, AbelaRidder B, Punderson J W, Fedorko DP and Foley S L (2003): An overview of Salmonella typing Public health perspectives. Clinical and Applied Immunology Reviews, 4: 189-204.

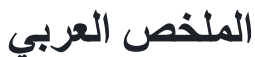 \\ التحليل الجزيئي لبعض جينات الضر اوه المعزولة من الاجاج في محافظة الثرقيه}

اللو اجن هي واحدة من أكثر مصادر السالمونيلا التي يمكن أن تتنقل إلى الإنسان من خلال

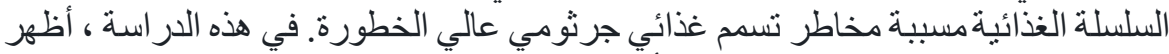

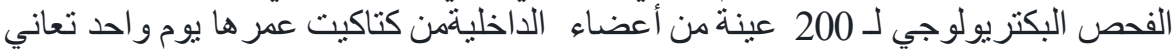

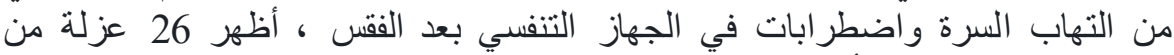

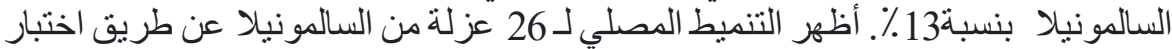

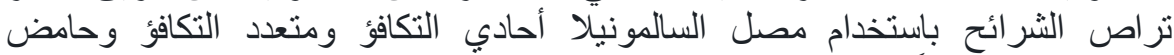

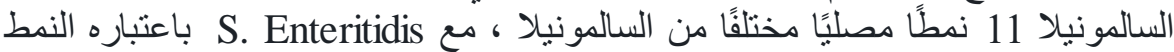

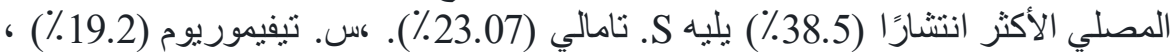

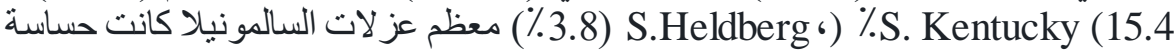

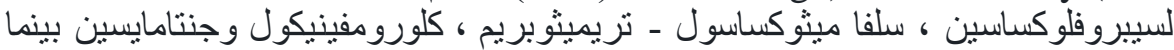

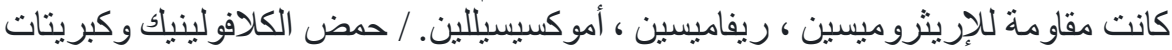

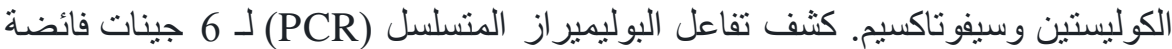

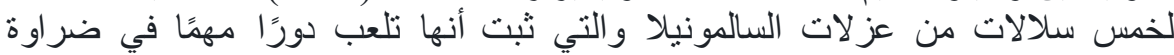

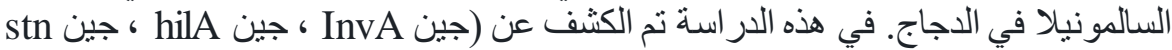

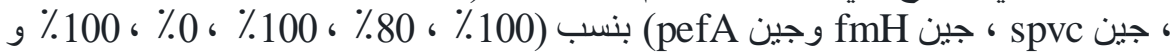

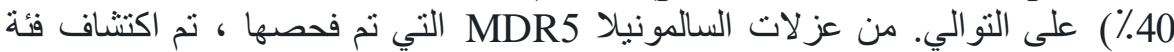

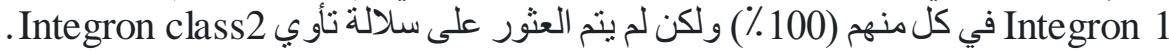

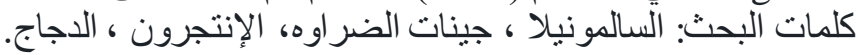

